$M i t j a$ skubic

\title{
PRETERITO SIMPLE Y COMPUESTO EN EL ESPAÑOL HABLADO
}

1. Estas líneas no pretenden ser más que una mođesta contribución a una más amplia y profunda encuesta sobre el empleo de las dos formas del pretérito en el español contemporáneo. Se trata de unas cuantas frasęs oídas en el otoño de este año en varias ciudades españolas.

No he tenido en cuenta ni distinción social, ni edad. La edad se precisará sólo cuando se tratará del habla de los niños y personas jóvenes. Ninguna de las frases citadas representa la traducción o la respuesta a una pregunta formulada con el fin de obtener una frase con la forma verbal que nos interesa. En la mayoria de los casos, los pasajes han sido recogidos en las conversaciones entre otras personas; $\mathrm{y}$ no conmigo, 10 que probablemente elimina el empleo de una de las dos formas que él que habla considera más literaria.

2. Para la exposición teórica ${ }^{1}$ partimos de las tres oposiciones: Ia primaria con sus valores aoristo: perfecto; las demás secundarias y las dos formas del pretérito representan acción puntual y acción no puntual o acción lejaria y acción reciente respectivamente.

3. Buscando precisar de que forma se sirve el que habla, precisaremos primeramente que una narración ${ }^{2}$ es presentada, casi siempre, con la forma simple:

- Después que nos separamos, nos fuímos a la casa del Greco, después visitamos una iglesia, vimos allí un magnífico cuádro del Greco, salimos hasta el río y ahora estamos aquí

(Murcia, 18 años)

- Yo vine aquí a las cinco de la tarde y dormi aquí en salamanca; y ellos durmieron en Zamora y han venido aquí hoy por la mañana.

- Nosotros dormimos en Zamora y venimos aquí a las cinco de la mañana

(tres estudiantes de Zamora, 18 años)

i Vease, en la misma revista, vol. V., el artículo sobre el empleo de las dos formas del pretérito en los trovadores y el artículo Pretérito simple y compuesto en los primeros textos cástellanos en Actas del XI Congreso Internacional de Lingüistica y Filología Románicas, Madrid, 1965.

2 Todos los chicos ( $7-12$ años) en Sevilla, Granada, etc. cuentan en el pretérito simple las acciones ocurridas la misma mañana: nEsta mañana me desperté a las siete, me levanté, tomé ... 
Es visible la cadena de acciones. Tal vez, un imperfecto es bastante para crear la posibilidad de acumular acciones preteritales:

- To le vi cuando en la tienda preguntaba por el pan

(Córdoba, 14 años).

4. Resulta de estos ejemplos que el empleo del pretérito simple es posible, y muy frecuente, en una narración aunque ésta se refiera a hechos de un. pasado reciente.

Es normal encontrar el pretérito simple para una acción aislada ocurrida en un pasado lejano:

- El año pasado llovio poco

(Palencia)

- Cuando termino la guerra

\section{(Madrid)}

Es más raro oír la forma simple para una accionn aislada, perteneciente al pasado reciente, como por ejemplo en las frases siguientes:

- Vd. gusta? - No gracias. Terminé ahora mismo

(Granada)

- Yo cogi esta mañana la moto

(Avila, 16 años)

Sin embargo, la forma más empleada parece la compuesta:

- El público ha pedido dos orejas, y no se las han dado

(Burgos)

- ha empezado a las nueve el partido

(Madrid)

Es decir que en castellano hablado existe la oposición acción lejana: acción reciente, pero, que el pretérito simple puede expresar, a veces, una acción reciente.

5. El empleo de la forma analítica del pretérito es normal ${ }^{3}$ cuando se expresa una acción no ṕuntual:

- me lo ha dicho veinte veces

$$
\text { - Ha estado Va ya en Alicante? }
$$

(Córdoba)

(Alicantè)

Ocurre lo mismo en las frases negativas:

- No ha llegado todavía

- No he estado nunca en Bilbao

(Córdoba)

(Zamora)

3 Oido una sola vez, de un gallego: "Yo estuve en Madrid muchas vecesu. 
Al contrario, se encuentra la forma simple cuando hāy una locución adverbial que precise, delimite la acción verbal:

- Estuve desde las dos hasta las cinco delante la taquilla

(Málaga; oído a las seís y media de la tarde)

6. Lo más difícil es establecer la existencia de la oposición primaria. La forma compuesta, aquí, expresa un perfecto, un estado en el presente:

- Lo que ha hecho Real Madrid, no ha hecho ningun otro equipo

(Madrid)

- (el tabaco) ya se le (ha) acabado

(Palencia)

Pero, en castellano contemporáneo es siempre posible expresar una acción pretérita pura, una acción concluáda, aunque, excepto la forma verbal, no haya nada que precisara una açción pretérita:

- Profesor, ya entregó su ponencia?

(Granada)

- Si el país no me gusta, yo me voy y, se acabó

(Madrid)

- Ei tiempo cambia, ya acabó el verano

(Oviedo)

- Comiste la manzana?

(Jaen)

- No se torea el toro dos veces... ya lo aprendió

(Madrid)

7. De los pocos ejemplos no es posible sacar conclusiones seguras. De ellos se deduce (y una encuesta, quizás, lo confirmaría) que el pretérito simple no es tan frecuente en Castilla como en algunas otras regiones de E'spaña.

Además, parece que existen lass tres oposiciones. En la primaria encontramos el pretérito simple muy frecuentemente, también en situaciones donde no es usual en los demás idiomas románicos. En la oposición secundaria acción lejana : acción reciente vemos que el pretérito simple no es imposible en las acciones de un pasado reciente, lo que significa que la oposición no es muy sólida. Sólo en la oposición secundaria acción puntual : acción no puntual las dos formas del pretérito no pueden sustituirse la una por la otra: es la oposición más firme, prọbablemente la más vieja. 


\section{POVZETEK}

V. želji, da bi bila uporaba enostavnega in sestavljenega preterita na romanskih tleh čimbolj poznana, je skušal avtor zbrati nekaj podatkov o rabi teh oblik $v$ govorjeni španščini. Da bi bila slika čimbolj verna, ni izvedel nikakšne, ankete; vsi navedeni primeri so vzeti iz pogovorov, največkrat celo iz pogovorov med samimi Șpanci.

To je tudi yzrok, da je število zapisanih primerov majhno; in vendar dovoljujejo ti trditi, da so vse tri opozicije, iz katerih avtor izhaja (prim. Linguistica.v, str. 61 ss.), v govorjeni -španščini žive: Bolj široko izvedena anketa bo najbrž tudi ugotovila, da je enostavni preterit bolj trdoživ $v$ nekaterih obrobnih pokrajinah kot pa v Kastiliji. 